\begin{tabular}{|ll|}
\hline Received & $:$ 30 Maret 2019 \\
Revised & $: 4$ April 2019 \\
Accepted & $: 22$ April 2019 \\
Online & $: 28$ April 2019 \\
Published & $:$ 30 April 2019 \\
\hline
\end{tabular}

\title{
UJI TEKANAN DAN DAYA SERAP AIR PADA BATAKO BERBAHAN DASAR CAMPURAN LIMBAH STYROFOAM, SERAT KELAPA, DAN ABU GOSOK
}

\author{
Andreansyah $^{1)}$, Rahma Rosaliana Saraswati ${ }^{2)}$, Ersa Ayu Lestari ${ }^{3)}$ \\ ${ }^{1}$ Fakultas Teknik, Universitas Negeri Jakarta \\ Email : andreansyah55@gmailcom \\ ${ }^{2}$ Fakultas Matematika dan Ilmu Pengetahuan Alam, Universitas Negeri Jakarta \\ Email:2rahma.rosaliana@gmail.com \\ ${ }^{3}$ Fakultas Teknik, Universitas Negeri Jakarta \\ Email : ${ }^{3}$ lestariersaayu@gmail.com
}

\begin{abstract}
The aim of the research is to produce an environmentally friendly brick and also know the pressure and water absorption of the concrete- based concrete mixture of styrofoam waste, coconut fiber, and rubbing ash. The method used in this research is quantitative experimental research method. Based on the test results, it can be concluded that in order to achieve maximum pressure the composition of the waste should be $25 \%$ and to achieve the minimum absorption, the composition of the waste should be $50 \%$. Batako with a waste composition of $25 \%$ and $50 \%$ can be categorized as suitable for use based on the results of compressive strength and water absorption. Meanwhile, concrete blocks with $75 \%$ waste are not suitable for use because the results of pressure testing are below the minimum standard SNI No. 03-0349 in 1989.
\end{abstract}

Keywords: Brick, Compressive Strength, Absorption

\begin{abstract}
Abstrak
Tujuan dari penelitian ini adalah untuk menghasilkan batu bata yang ramah lingkungan dan juga mengetahui tekanan dan penyerapan air dari campuran beton berbasis beton dari limbah styrofoam, serat kelapa, dan abu gosok. Metode yang digunakan dalam penelitian ini adalah metode penelitian eksperimental kuantitatif. Berdasarkan hasil pengujian, dapat disimpulkan bahwa untuk mencapai tekanan maksimum komposisi limbah harus $25 \%$ dan untuk mencapai penyerapan minimum, komposisi limbah harus 50\%. Batako dengan komposisi limbah 25\% dan 50\% dapat dikategorikan cocok untuk digunakan berdasarkan hasil kuat tekan dan daya serap air. Sementara itu, balok beton dengan limbah $75 \%$ tidak cocok untuk digunakan karena hasil pengujian tekanan di bawah standar minimum SNI No. 03-0349 pada tahun 1989.
\end{abstract}

Kata kunci: Bata, Kekuatan Tekan, Penyerapan.

\section{PENDAHULUAN}

Di era revolusi industri 4.0 ini, salah satu isu yang paling sering dibicarakan adalah masalah pemanasan global. Pemanasan global mengakibatkan perubahan iklim yang pada akhirnya menyebabkan bencana yang berpotensi akan menghancurkan bumi. Pemanasan global disebabkan oleh beberapa faktor, salah satunya adalah limbah. Limbah memiliki potensi untuk memberi sumbangan terhadap meningkatnya emisi gas rumah kaca, peristiwa ini terjadi pada penumpukan limbah tanpa diolah yang melepaskan gas metan $\left(\mathrm{CH}_{4}\right)$. Limbah memiliki daya dukung yang besar terhadap emisi gas rumah kaca yaitu gas metan $\left(\mathrm{CH}_{4}\right)$. Setiap 1 ton sampah padat menghasilkan $50 \mathrm{~kg}$ gas $\mathrm{CH}_{4}$ (Sudarman,2010). 
Di sisi lain, pembangunan infrastruktur juga sedang berkembang dengan sangat pesat. Pada umumnya, pembangunan ini tidak lepas dari penggunaan batu bata sebagai salah satu pembentuk konstruksi dinding dalam suatu pembuatan bangunan. Hal ini dikarenakan oleh kebutuhan batu bata yang semakin meningkat, maka pengikisan tanah yang disebabkan oleh pembuatan batu bata menjadi masalah di lapangan yang harus segera diatasi.

Styrofoam merupakan salah satu jenis limbah anorganik. Styrofoam biasa digunakan untuk kehidupan sehari - hari, seperti tempat makanan dan minuman, pembungkus dan pengaman barang elektronik, untuk dekorasi dan sebagainya. Limbah styrofoam merupakan masalah lingkungan yang berat, semakin hari semakin banyak, dan tidak bisa membusuk, sehingga timbunan sampah styrofoam akan terus bertambah apabila tidak didaurulang. Salah satu cara untuk mendaur ulang limbah styrofoam yaitu dengan pemanfaatan styrofoam sebagai bahan bangunan salah satunya adalah batako. Berdasarkan hasil penelitian yang dilakukan Abdul Halim (2013) menyatakan bahwa penambahan styrofoam pada batako dapat memperingan batako hingga 13\%. Dalam skala besar styrofoam telah dimanfaatkan sebagai bahan dinding bangunan, stabilitas lereng dan lain - lain.

Pengertian batako adalah salah satu bahan bangunan yang berupa batu batuan yang pengerasannya tidak dibakar dengan bahan pembentuk yang berupa campuran pasir, semen, air dan dalam pembuatannya dapat ditambahkan bahan tambahan lainnya (aditif). Kemudian dicetak melalui proses pemadatan menjadi bentuk balok-balok dengan ukuran tertentu.

Menurut pasal 6 persyaratan umum bahan bangunan di Indonesia (1982), "Batako adalah bata yang dibuat dengan mencetak dan memelihara dalam kondisi lembab". Batako terdiri dari dua jenis, yaitu batako jenis berlubang (hallow) dan batako yang padat (solid).

Batako (hollow) adalah batako yang memiliki penampang lubang lebih dari $25 \%$ luas penampang batanya, dan volume lubang lebih dari $25 \%$ volume batas seluruhnya. Sedangkan batako (solid) memiliki penampang pejal $75 \%$ atau lebih dari luas penampang seluruhnya, dan memiliki volume pejal lebih dari $75 \%$ volume bata seluruhnya.

Kekuatan dari batako dipengarui oleh komposisi penyusunannya yaitu jenis semen dan pasir yang dipakai, dan perbandingan jumlah semen terhadap agregat dan air. Batako yang baik adalah batako yang masing-masing permukaannya rata dan saling tegak lurus serta mempunyai kuat tekan yang tinggi. Sesuai dengan pemakaiannya batako diklasifikasikan dalam beberapa kelompok sebagai berikut: Batako dengan mutu A1, adalah batako yang digunakan hanya untuk konstruksi yang tidak memikul beban, dinding penyekat serta konstruksi lainnya yang selalu terlindung dari cuaca luar. Batako dengan mutu A2, adalah batako yang digunakan hanya untuk hal-hal seperti tersebut dalam jenis A1, hanya permukaan dinding/ konstruksi dari batako tersebut boleh tidak diplester. Batako dengan mutu B1, adalah batako yang digunakan untuk konstruksi yang memikul beban, tetapi penggunaannya hanya untuk konstruksi yang terlindung dari cuaca luar (untuk konstruksi di bawah atap), dan Batako dengan mutu B2, adalah batako untuk konstruksi yang memikul beban dan dapat digunakan pula untuk konstruksi yang tidak terlindung.

Penelitian yang relevan terhadap penelitian ini yaitu : Pemanfaatan Limbah Abu Batu Bara, Kulit Kerang, dan Abu Sekam Padi sebagai Bahan Substitusi Semen dan Pasir dalam Pembuatan Batako oleh M. Syukur dan S.Dharma dengan hasil penelitian yaitu, Tekanan batako dengan bahan dasar abu batu bara, kulit kerang, dan abu sekam padi berada di dalam tipe II berdasarkan standar SNI akan tetapi untuk daya serap airnya berada di bawah standar. Penggunaan Serat Pelepah Kelapa Sawit asal Dumai sebagai Bahan Tambah Pembuatan Batako Serat oleh Zainuri, Guneli Yanti, dan Shanti Wahyuni Megasari dengan hasil penelitian Nilai kuat tekan dan penyerapan air batako serat lebih baik pada penambahan serat $1 \%$ yang memenuhi SNI dari berat semen. Pengaruh Pemakaian Limbah Styrofoam terhadap Kuat Tekan dan Berat Batako oleh Abdul Halim dengan hasil penelitian Berat batako semakin berkurang, pengurangan pasir diganti dengan styrofoam sebesar $33 \%$ akan mengurangi berat batako sebesar $13 \%$

Adapun yang menjadi pembeda antara penelitian ini dengan penelitian di atas adalah penelitian ini memakai ketiga jenis limbah di atas sekaligus, yaitu abu gosok, styrofoam. dan serat kelapa.

Limbah lainnya yang dapat dimanfaatkan untuk penggunaan bahan dasar batako adalah limbah serat kelapa. Pada umumnya serat kelapa dibiarkan menumpuk dengan harapan lambat laun akan hancur sendiri padahal serat kelapa yang termasuk dalam kategori limbah organik ini dapat menghasilkan 
metan. Dalam dunia konstruksi, serat digunakan sebagai bahan baku atau tambahan untuk membuat material bangunan seperti eternit dan beton serat. Berdasarkan hasil penelitian Intara (2012), menyatakan bahwa sifat fisik dan mekanik serat kelapa sawit menunjukkan adanya harapan untuk menggunakan bahan kering dari serat pelepah kelapa sawit yang setara dengan kekuatan rotan sedangkan pemanfaatan limbah serat pelepah kelapa sebagai bahan dasar batako digunakan untuk menambah daya serap air pada batako.

Limbah selanjutnya yang dapat dimanfaatkan adalah limbah abu gosok yang berasal dari hasil pembakaran limbah sekam padi, tempurung kelapa atau kayu yang tidak terpakai. Abu gosok mengandung calsium carbonat mesh yang reaktif yang dapat bereaksi dengan hasil hidrasi semen berupa calsium hidroksida $\mathrm{Ca}(\mathrm{OH})_{2}$ sehingga penggunaannya pada campuran beton limbah ini diharapkan dapat meningkatkan kepadatan dan rekatan antara partikel-partikel beton.

Dalam penelitian ini, mencoba untuk membuat batako ramah lingkungan yang berasal dari campuran limbah styrofoam, serat kelapa, serta abu gosok lalu mencari tahu karakterisasinya. Diharapkan hasil pembuatan dan pengujian tekanan serta daya serap batako ini sesuai dengan kriteria SNI No. 03-0349 tahun 1989 pada pasangan bata beton sehingga dapat digunakan pada konstruksi bangunan sebagai pengganti batu bata. Dengan adanya batako ini diharapkan dapat mengurangi pengikisan tanah yang disebabkan oleh pembuatan batu bata dan menjadi solusi untuk mengurangi gas rumah kaca penyebab pemanasan global.

\section{METODE PENELITIAN}

Penelitian ini menggunakan pendekatan kuantitatif karena sangat cocok untuk menguji terhadap adanya keragu-raguan tentang validitas pengetahuan, teori dan produk tertentu (Sugiyono, 2016). Tujuan Penelitian Kuantitatif adalah untuk mengembangkan dan menggunakan model-model matematis, teori-teori dan hipotesis yang dikaitkan dengan fenomena alam. Penelitian kuantitatif yang dilakukan pada penelitian ini menggunakan metode penelitian eksperimental.

\section{Kerangka Berpikir}

Kerangka berpikir dari penelitian ini yaitu, adanya limbah styrofoam, kelapa sawit, dan abu gosok. Limbah tersebut diolah menjadi adona batako. Lalu, dicetak menjadi batako. Setelah batako jadi, selanjutnya batako diuji tekanan dan daya serapnya. Dalam proses pengujiannya, batako terus dikontrol dan dirawat agar tetap dalam kondisi baik.

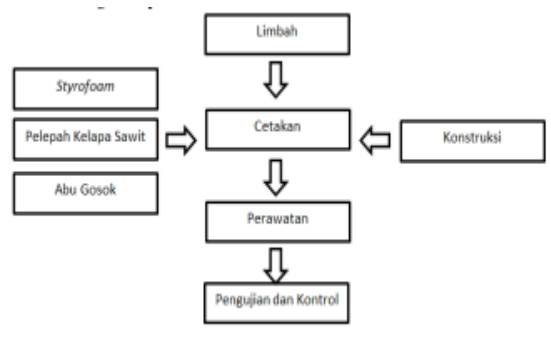

Gambar 1. Kerangka Berpikir

\section{Variabel Penelitian}

Variabel dari penelitian ini ada dua yaitu variabel bebas dan variabel terikat. Variabel bebasnya adalah variasi styrofoam, serat kelapa dan abu gosok sebesar 0\%, 25\%, 50\%, 75\% dari volume batako. Sedangkan variabel terikatnya adalah kuat tekan dan daya serap batako. Benda uji untuk uji kuat tekan dan daya serap air beton berbentuk balok dengan ukuran $36 \mathrm{~cm}$ x $15 \mathrm{~cm}$ x $9 \mathrm{~cm}$.

\section{Teknik Pengumpulan Data}


Teknik pengumpulan data dalam penelitian ini adalah Studi Pustaka dilakukan dengan mengumpulkan data dengan cara membaca dari berbagai literatur seperti artikel ilmiah, jurnal, internet, buku, dan bahan bacaan lainnya yang berkaitan dengan pembahasan penelitian. Dan Observasi yaitu melakukan pengamatan secara langsung di lokasi penelitian terhadap obyek yang akan diteliti dan dibahas serta mengumpulkan data atau informasi sebanyak mungkin yang berhubungan dengan masalah yang akan diteliti (Magfirah, 2012).

\section{HASIL DAN PEMBAHASAN \\ Pembuatan Batako}

Sebelum memulai membuat adonan batako, langkah pertama yang harus dilakukan adalah menyiapkan alat dan bahan. Adapun alat dan bahan yang harus disiapkan adalah cetakan batako, abu gosok, semen, styrofoam, pasir, dan serabut kelapa. Setelah itu, membuat adonan dengan mencampur bahan - bahan yang telah disiapkan dengan komposisi sebagai berikut.

Tabel 1. Komposisi Adonan Batako

\begin{tabular}{|c|c|c|c|c|c|c|}
\hline $\begin{array}{c}\text { Jenis } \\
\text { Batako }\end{array}$ & Volume Pasir & $\begin{array}{c}\text { Volume } \\
\text { Semen }\end{array}$ & $\begin{array}{c}\text { Volume } \\
\text { Air }\end{array}$ & $\begin{array}{c}\text { Volume } \\
\text { Serabut } \\
\text { Kelapa }\end{array}$ & $\begin{array}{c}\text { Volume } \\
\text { Styrofoam }\end{array}$ & $\begin{array}{c}\text { Volume } \\
\text { Abu Gosok }\end{array}$ \\
\hline $25 \%$ & $1.365,375 \mathrm{~cm}^{3}$ & $2.275,625 \mathrm{~cm}^{3}$ & 1 Liter & $405 \mathrm{~cm}^{3}$ & $405 \mathrm{~cm}^{3}$ & $405 \mathrm{~cm}^{3}$ \\
\hline $50 \%$ & $911,25 \mathrm{~cm}^{3}$ & $1.518,75 \mathrm{~cm}^{3}$ & 1 Liter & $810 \mathrm{~cm}^{3}$ & $810 \mathrm{~cm}^{3}$ & $810 \mathrm{~cm}^{3}$ \\
\hline $75 \%$ & $455,625 \mathrm{~cm}^{3}$ & $759,375 \mathrm{~cm}^{3}$ & 1 Liter & $1.215 \mathrm{~cm}^{3}$ & $1.215 \mathrm{~cm}^{3}$ & $1.215 \mathrm{~cm}^{3}$ \\
\hline
\end{tabular}

\section{Pengujian Batako}

Hasil Pengujian Terhadap Tekanan Batako dilakukan pada 3 jenis sampel batako dengan variasi komposisi limbah sesuai dengan Tabel 1. Adapun data hasil pengujian kuat tekan ditunjukkan pada Tabel 2 sebagai berikut.

Tabel 2. Hasil Pengujian Tekanan

\begin{tabular}{|c|c|c|c|c|}
\hline $\begin{array}{c}\text { Nomor } \\
\text { Sampel }\end{array}$ & $\begin{array}{c}\text { Komposisi } \\
\text { Limbah (\%) }\end{array}$ & $\begin{array}{c}\text { Gaya Tekan } \\
(\mathrm{N})\end{array}$ & $\begin{array}{c}\text { Luas } \\
\text { Penampang }\left(\mathrm{m}^{2}\right)\end{array}$ & $\begin{array}{c}\text { Tekanan } \\
(\mathrm{Mpa})\end{array}$ \\
\hline I & 25 & 325.000 & $1,35 \times 10^{-2}$ & 24,074 \\
\hline II & 50 & 155.000 & $1,35 \times 10^{-2}$ & 11,481 \\
\hline III & 75 & 85.000 & $1,35 \times 10^{-2}$ & 6,296 \\
\hline
\end{tabular}

Berdasarkan hasil pengujian,maka batako dengan komposisi limbah 25\% memiliki tekanan 24,074 Mpa, sedangkan batako dengan komposisi limbah 50\% memiliki tekanan 11,481 Mpa. Lalu, batako dengan komposisi limbah 75\% memiliki tekanan 6,296 Mpa.

Hasil Pengujian Terhadap Daya Serap Air Batako dilakukan pada 3 jenis sampel batako dengan variasi komposisi limbah sesuai dengan Tabel 1 Adapun data hasil pengujian daya serap air ditunjukkan pada Tabel 3 sebagai berikut : 
Tabel 3. Hasil Pengujian Daya Serap Air

\begin{tabular}{|c|c|c|c|c|}
\hline Nomor Sampel & $\begin{array}{l}\text { Komposisi } \\
\text { Limbah (\%) }\end{array}$ & $\begin{array}{l}\text { Berat Batako } \\
\text { Kering (kg) }\end{array}$ & $\begin{array}{l}\text { Berat Batako + } \\
\text { air (kg) }\end{array}$ & Daya Serap Air \\
\hline I & 25 & 9,32 & 9,55 & $2,47 \%$ \\
\hline II & 50 & 9,92 & 10,13 & $2,19 \%$ \\
\hline III & 75 & 7,58 & 7,93 & $4,62 \%$ \\
\hline
\end{tabular}

Berdasarkan hasil pengujian, maka batako dengan komposisi limbah $25 \%$ memiliki daya serap air sebesar 2,47\%, sedangkan batako dengan komposisi limbah 50\% memiliki daya serap air sebesar 2,19\%. Lalu, batako dengan komposisi limbah $75 \%$ memiliki daya serap air sebesar 4,62\%.

\section{Hasil Analisis Data}

Berikut adalah hasil pengujian tekanan terhadap batako limbah.

Tabel 4. Analisis Pengujian Tekanan

\begin{tabular}{|c|c|c|c|}
\hline No. & Komposisi Limbah & Tekanan (Mpa) & Kelayakan \\
\hline 1. & $25 \%$ & 24,074 & Layak \\
\hline 2. & $50 \%$ & 11,481 & Layak \\
\hline 3. & $75 \%$ & 6,296 & Tidak Layak \\
\hline
\end{tabular}

Bedasarkan standar SNI No. 03-0349 tahun 1989 pada Tabel 1 menyatakan bahwa, syarat minimum tekanan bruto masing - masing batako yaitu sebesar $90 \mathrm{~kg} / \mathrm{cm}^{3}$ atau apabila dikonversi dalam satuan Mpa yaitu sebesar 8,82598 Mpa. Hasil pengujian menunjukan bahwa, tekanan batako dengan komposisi limbah 25\% dan 50\% berturut - turut adalah 24,074 Mpa dan 11,481 Mpa. Hal ini berarti batako dengan komposisi limbah $25 \%$ dan 50\% dapat dikategorikan layak untuk digunakan Sedangkan, batako dengan komposisi limbah 75\% memiliki tekanan 6,296 Mpa atau termasuk ke dalam kategori tidak layak.

Berikut adalah hasil pengujian daya serap air terhadap batako limbah :

Tabel 5. Analisis Pengujian Daya Serap Air

\begin{tabular}{|c|c|c|c|}
\hline No. & Komposisi Limbah & Daya Serap Air (\%) & Kelayakan \\
\hline 1. & $25 \%$ & $2,47 \%$ & Layak \\
\hline 2. & $50 \%$ & $2,19 \%$ & Layak \\
\hline 3. & $75 \%$ & $4,62 \%$ & Layak \\
\hline
\end{tabular}

Berdasarkan standar SNI No. 03-0349 tahun 1989 pada Tabel 1 menyatakan bahwa, syarat maksimum daya serap air yaitu sebesar $25 \%$. Hasil pengujian menunjukan bahwa, daya serap batako dengan komposisi limbah 25\%, 50\%, dan $75 \%$ berturut - turut adalah 2,47\%, 2,19\%, dan 4,62\%. Hal ini berarti batako dengan komposisi limbah 25\%, 50\%, 75\% dapat dikategorikan layak untuk digunakan. 


\section{KESIMPULAN}

Tekanan batako dengan komposisi limbah 25\% dan 50\% berturut - turut adalah 24,074 Mpa dan 11,481 Mpa atau tergolong layak digunakan berdasarkan standar SNI No. 03-0349 tahun 1989. Batako dengan komposisi limbah 75\% memiliki tekanan 6,296 Mpa atau termasuk ke dalam kategori tidak layak digunakan berdasarkan standar SNI No. 03-0349 tahun 1989. Daya serap batako dengan komposisi limbah $25 \%, 50 \%$, dan $75 \%$ berturut - turut adalah $2,47 \%, 2,19 \%$, dan 4,62\% atau tergolong layak digunakan berdasarkan standar SNI No. 03-0349 tahun 1989.

\section{REFERENSI}

Abdurrahman, U. (2006). Kinerja Sistem Lumpur Aktif pada Pengolahan Limbah Cair Laundry . Tugas Akhir. Jurusan Teknik Lingkungan.

Achmadi, N. d. (2007). Metodologi Penelitian. Jakarta: Bumi Aksara.

Anugraha, R. B. (2010). Beton Ringan dari Campuran Styrofoam dan Serbuk Gergaji dengan Semen Portland 250, 300, dan $350 \mathrm{~kg} / \mathrm{m} 3$.

Hadi, M. (2004). Teknik Berkebun Kelapa Sawit. Yogyakarta: Adicita.

Halim, A. (2013). Pengaruh Pemakaian Limbah Sterofoam terhadap Kuat Tekat dan Berat BAtako. Widya Teknika 2(1), 1 - 7 .

Syukur, S. D. (t.thn.). Pemanfaatan Limbah Abu Batu Bara, Kulit Kerang, dan Abu Sekam Padi sebagai Bahan Substitusi Semen dan Pasir dalam Pembuatan Batako.

Ramlan, M. (2002). Pemanasan Global. Jurnal Teknologi Lingkungan,3(1), 30 - 32.

Sudarman. (2010). Meminimalkan Daya Dukung Sampah. PROFESIONAL, 8(1), $51-59$.

Sugiyono. (2016). Metode Penelitian Kuantitatif, Kualitatif, dan $R \& D$. Bandung: Alfabeta, cv.

Waluyo, L. (2005). Bioremidiasi Limbah Domestik Ramah Ligkungan :Uji Antagonistik Isolat Actynomycetes dan Fungi dari Limbah Septi Tank, Comberan, dan Bekas Air Mandi terhadap Bakteri Pantogen. Laporan Program Penelitian Unggulan (P2U).

Zainuri, Yanti, G., \& Megasari, S. W. (2017). Penggunaan Serat Pelepah Kelapa Sawit Asal Dumai Sebagai Bahan Tambah Pembuatan Batako Serat. Jurnal Sainstek STT Pekanbaru, 5(2), 52 - 58. 